\title{
Core-to-Cubic Strength Ratio for Historical-Like Concrete
}

\author{
Antonio Brencich*, Fahdi Hasweh, Davide Pera \\ Department of Civil, Chemical and Environmental Engineering, University of Genoa, via Montallegro 1, 16145 Genoa, Italy
}

Received December 18, 2020; Revised January 18, 2021; Accepted February 24, 2021

\section{Cite This Paper in the following Citation Styles}

(a): [1] Antonio Brencich, Fahdi Hasweh, Davide Pera , "Core-to-Cubic Strength Ratio for Historical-Like Concrete," Civil Engineering and Architecture, Vol. 9, No. 2, pp. 339 - 346, 2021. DOI: 10.13189/cea.2021.090207.

(b): Antonio Brencich, Fahdi Hasweh, Davide Pera (2021). Core-to-Cubic Strength Ratio for Historical-Like Concrete. Civil Engineering and Architecture, 9(2), 339 - 346. DOI: 10.13189/cea.2021.090207.

Copyright $\odot 2021$ by authors, all rights reserved. Authors agree that this article remains permanently open access under the terms of the Creative Commons Attribution License 4.0 International License

\begin{abstract}
Coring is considered to provide the best estimate of concrete compressive strength in existing structures and is commonly used to calibrate Non-Destructive and Moderately Destructive Techniques. Historical concrete, produced in the pre-code period until the '20s, significantly differs from modern concrete due to lack of standardization, improper rules of thumbs and to aggregate shape (round, smooth and often excessively large aggregates) and proportioning. Therefore, the applicability of the procedures calibrated on modern concrete to a historical one, also coring, is an issue that needs to be discussed. In this paper, an experimental campaign on historical-like concrete, i.e. with the same defects as historical concrete, aims at identifying the reliability of drilled cores due to the effect of round aggregates. The results show that standard procedures commonly used on modern concrete cannot be directly applied to historical concrete: drilled cores suffer from scale effects (core diameter) and from cutting damage of the material much more than modern concrete. In detail, the core-to-cubic ratio, that modern codes assume in the range $0.70-0.85$, due to the dimension and shape of the aggregates is found inside a larger range, $0.70-1.00$, and, as opposed to modern concrete, is found to be decreasing as concrete strength increases. Besides, the diameter of the core is found to have a relevant effect on the estimate of the material compressive strength and on the core-to-cubic strength ratio, pointing out that the dimension of the core affects the results much more than for modern concrete. This latter result, which needs further research, points out that historical concretes may be rather different from modern ones and probably need larger cores to be drilled than modern concrete due to the larger dimension of
\end{abstract}

aggregates that are often found in pre-code concrete.

Keywords Historical Concrete, Compressive Strength, Cores, Core-to-Cubic Ratio

\section{Introduction}

One of the main drawbacks of coring a reinforced concrete structure is the damage induced in the tested elements. If you consider a $300 \times 300 \mathrm{~mm}$ pillar, for example, drilling a $100 \mathrm{~mm}$ diameter core makes the average stress field increase some $50 \%$ and, even though you may fill the core with expansive mortar, the initial stress state will never be recovered. This introduces permanent damage in the structural element that prevents cores from being used extensively, even though they are considered to provide the most reliable estimate of concrete compressive strength. Alternative methods, called Non Destructive and Moderately Destructive Tests [1-4], in spite of a huge amount of academic research, are not yet able of providing fully reliable estimates and still need to be compared and corroborated by core data [4-8, among the latest results].

The relationship between the core and the cylindrical/cubic strength of concrete, i.e. in situ vs standard laboratory strength of concrete, has long been discussed by the academic community [9-13 among the others] and are still nowadays research issues [14-19]. Even though several parameters affecting the core strength have been studied, modern codes honestly admit that: "There is no unique relationship between the 
compressive strength of a core and the corresponding compressive strength of standard-cured moulded cylinders. The relationship is affected by many factors such as the strength level of the concrete, the in-place temperature and moisture histories, the degree of consolidation, batch-to-batch variability, the strength gain characteristics of the concrete, the condition of the coring apparatus and the care used in removing cores. Historically, it has been assumed that core strengths are generally $85 \%$ of the corresponding standard-cured cylinder strengths, but this is not applicable to all situations", as ASTM C42 [20] states in section 3.5. Furthermore, "There is no universally accepted method for determining the $10 \%$ fractile of the in-place strength", as per ACI 214.4 in section 8.4 [21].

Historical concrete, i.e. the concrete produced before building codes had been issued or before the provisions of the codes entered the professional and building practice, is somehow more troublesome since it is characterized by large and smooth aggregates [22-24], high porosity and high inhomogeneity [25-27], all parameters that may significantly affect the compressive strength. All these "defects", and mainly the use of large and smooth aggregates, add further uncertainty to the compressive strength and need a verification if the procedures already tested on modern concrete, although affected by some approximation, may be applied, and to which extent, to historical concrete.

To gain a further insight in this issue, in this paper, a historical-type concrete (large and smooth aggregates, excess in water content, low strength), used also for calibrating a post-installed insert for pull-out [26] is used to compare the strength measured on drilled cores to the standard cubic strength.

\section{The Experimental Program}

\subsection{Concrete}

Pre-code concretes differ from modern ones because of several parameters:

i). the aggregate mixture was based just on the company experience and not any rational proportioning criteria. In the Hennebique patent, for example, no provision was given about water, which amount was left to the building site according to the required workability;

ii). river gravels were commonly used, being less expensive, so that the aggregate surfaces were smooth;

iii). severe excess in water, with water/cement ratio sometimes larger than 1.0;

iv). in general, the compressive strength is rather low for residential buildings, in-between 5 to $15 \mathrm{MPa}$, while in industrial and infrastructural facilities medium-to-high strength concrete may be found.

The aggregate mixture for the historical-like concrete, defined according to a weight criterion, assumed $50 \mathrm{~kg}$ of round coarse aggregate $(\max \phi=30 \mathrm{~mm})+50 \mathrm{~kg}$ of crashed medium aggregates $(\max \phi=15 \mathrm{~mm})+25 \mathrm{~kg}$ of crashed fine aggregates (max $\phi=3 \mathrm{~mm})+25 \mathrm{~kg}$ of sand ( $\max \phi=0.5 \mathrm{~mm}$ ), resulting in the sieve curve of figure 1 . It can be seen that pre-code concretes, as the one used in the tests, exhibit grading curves above the Fuller limits that are nowadays used for aggregate proportioning.

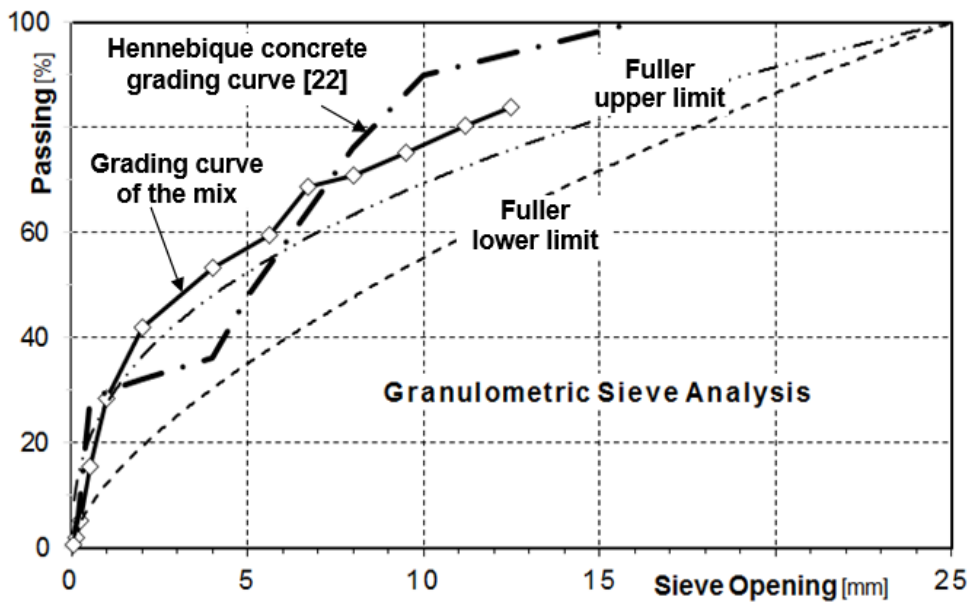

Figure 1. Granulometric sieve curve of the historical-like concrete used compared with the limit Fuller curves [29] 


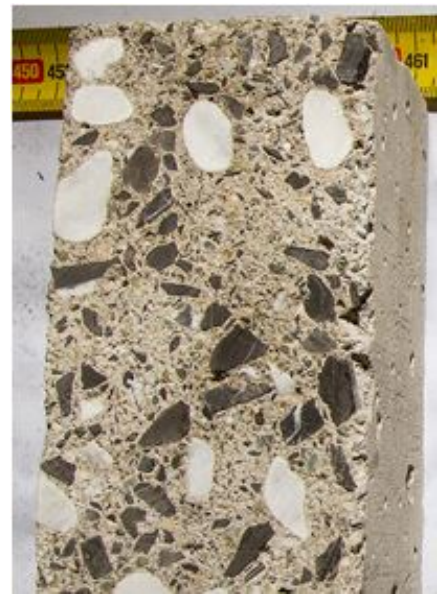

a)

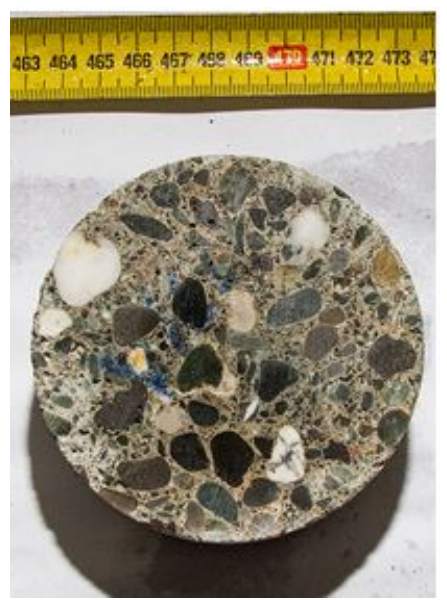

b)

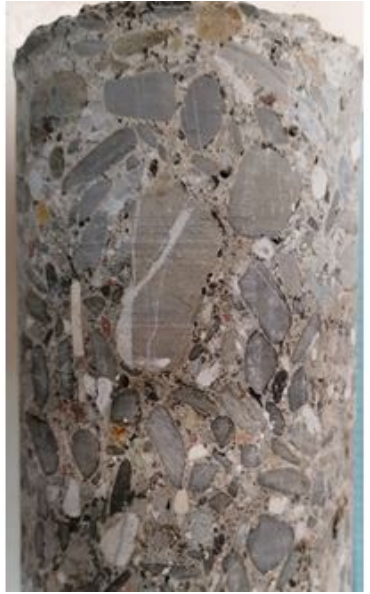

c)

Figure 2. Cross sections of: a) concrete produced for this research; b) cross section of a core extracted from a structure built by Porcheddu Building Company (residential building in the park of Villa Grüber, Genoa (Italy), 1920-1930 approx.); c) lateral surface of a core extracted from a residential building built in the ' 20 s

Table 1. Concrete strength and mixtures for the 5 historical-type concrete

\begin{tabular}{|c|c|c|c|c|c|c|}
\hline Concrete mix & $\begin{array}{l}\text { Cement } \\
{\left[\mathrm{kN} / \mathrm{m}^{3}\right]}\end{array}$ & $\begin{array}{c}\text { Cement } \\
\text { /batch }[\mathrm{kg}]\end{array}$ & Water/Cement ratio & $\begin{array}{c}\text { Porosity } \\
{[\%]}\end{array}$ & $\mathrm{R}_{\mathrm{c}, 28 \mathrm{days}}$ & $\begin{array}{l}\text { C.o.V. [\%] } \\
\text { (6 samples) }\end{array}$ \\
\hline Mix_1 & 2.0 & 18.2 & 1.0 & 8.3 & 8.4 & 3.2 \\
\hline Mix_2 & 3.0 & 27.3 & 0.8 & 8.6 & 14.5 & 2.2 \\
\hline Mix_3 & 4.2 & 38.3 & 0.6 & 8.3 & 25.8 & 2.8 \\
\hline Mix_4 & 5.0 & 45.5 & 0.5 & 7.3 & 29.9 & 0.5 \\
\hline Mix_5 & 1.5 & 13.6 & 1.2 & 10.0 & 7.2 & 9.1 \\
\hline
\end{tabular}

Figure 2 shows two sections: the rectangle, obtained from the concrete produced for this research, also visually resembles the round section obtained from a Hennebique structure (residential villa in Genoa, park of Villa Grüber, Porcheddu Building Company) and the lateral surface of a core drilled from a residential building built in the '20s.

Table 1 summarizes the main data on the five concrete types used, assuming a mix that includes the main defects of historical concrete: high porosity and severe bleeding. Further details on concrete performances may be found in the companion paper [28].

\subsection{Specimens}

For each type of concrete tested, 250x250x600mm prisms were produced along with and 16 cubes (150x150x150mm). In the specimen, face A is the one at free air, face B and D are the lateral surfaces while face C is the bottom one, figure 3 , so that the casting direction goes from face A to face $\mathrm{C}$. The prisms have been cured according to [30] and [31].

\subsection{Coring}

Considering the cone holes produced by pull-out tests [28], 2 large cores (93mm, named C1 and C2 in figure 4.a) and 3 small cores $(54 \mathrm{~mm}$ named $\mathrm{c} 1, \mathrm{c} 2$ and $\mathrm{c} 3$ in figure 4.a) could be drilled from each prism in parts of the specimens not affected by the pull-out tests. In this way 4 large cores and 6 small cores could be obtained from the two prisms used to calibrate the pull-out test. The cores were drilled transversally to the casting direction, figure 4 . 


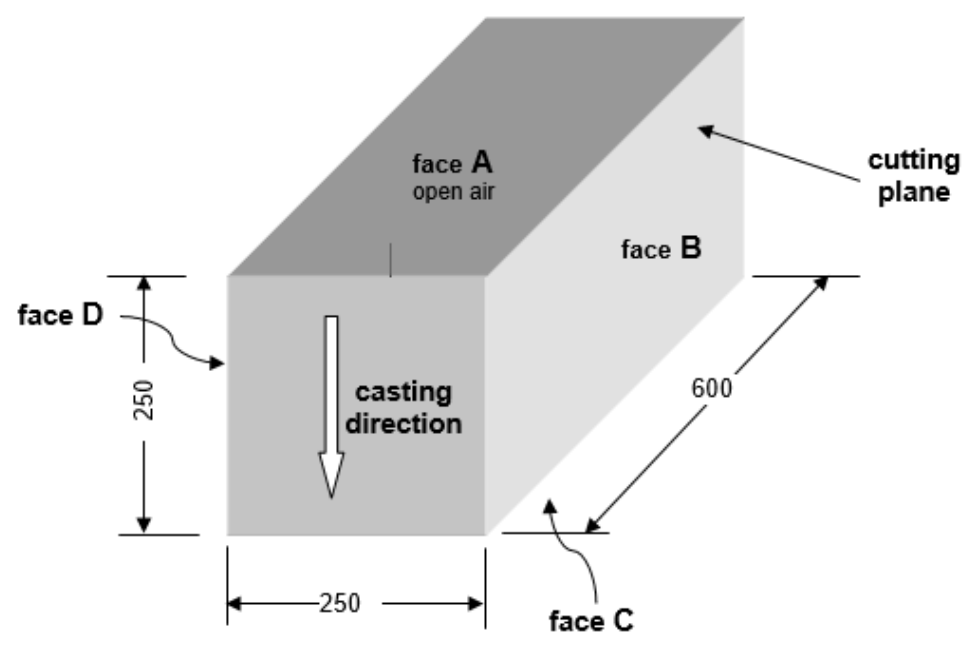

Figure 3. Identification of the prism faces and cutting plane.
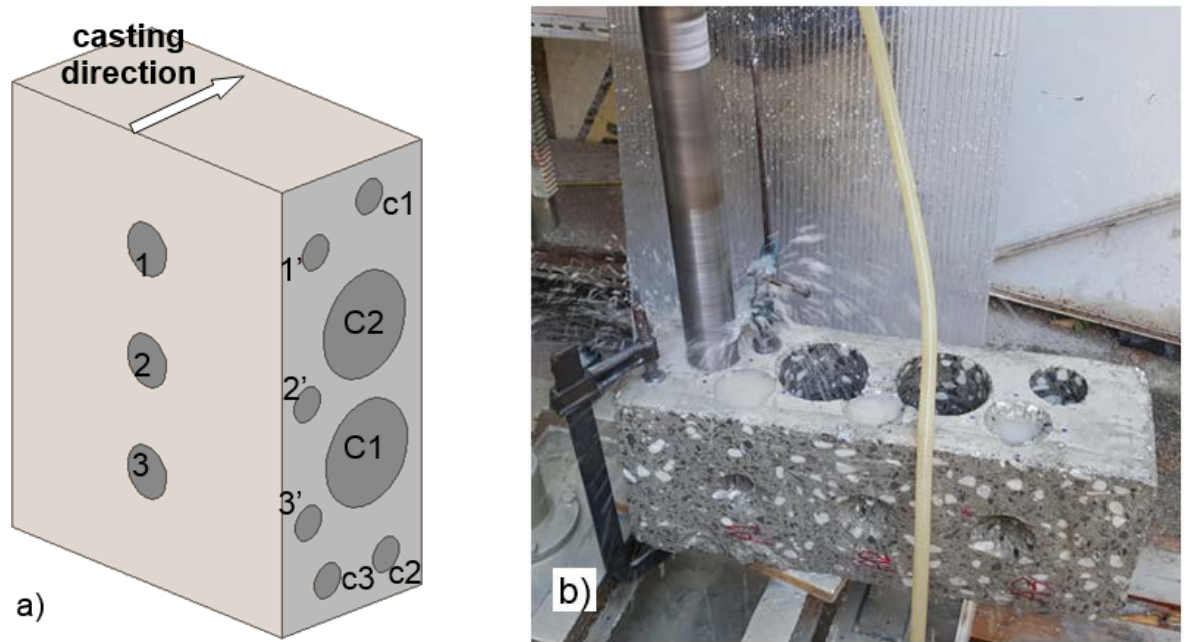

Figure 4. a) Cores in the prism. The numbers 1 to 3 and 1' to 3' refer to the craters left by the pull-out test; C1 and C2 are the locations for the 93mm cores and c1, c2 and c3 the smaller $54 \mathrm{~mm}$ cores; b) coring.

\subsection{Summary}

- 5 concrete types were used;

- standard concrete strength was obtained from cubic tests (16/mix) cured in standard conditions;

- 2 prims were produced for each concrete mix and cured in the same conditions as the cubes;

- 4 large cores (93mm) + 6 small cores (54mm) for each concrete mix (2 prisms/concrete mix) were drilled in the area of the specimens left undamaged by the pull-out tests of [28].

\section{Test Results}

As already discussed, a historical-type concrete is characterized by an excess in water content. This has two main consequences: i) concrete shows a (relatively) high porosity, table 1 ; ii) water blisters are formed either close to the upper surface of concrete (the one exposed to open air, such as face $A$ in this experimental campaign) and may be trapped below some large aggregate, figure 5 . This is expected to affect the concrete strength for water/cement ratio larger than 0.6 [32]. Figure 6 shows the lateral surface of two cores of MIX 1 and MIX 5, reproducing the phenomena of figure 5.

Two core diameters were drilled: $93 \mathrm{~mm}$ and $54 \mathrm{~mm}$ and their strength compared to the cubic strength measured the same day, which allowed drawing figures 7 and 8 . We can observe a general trend in which the core-to-cubic strength ratio decreases as the concrete strength increases. This is an unexpected outcome since most of the references (see [18] and [35] for a comprehensive review and [20] and [36] for an up-to-date code approach) on modern concrete shows that the core-to-cubic strength ratio increases as the concrete class increases, such as in figure 7 for [38] among the others. 

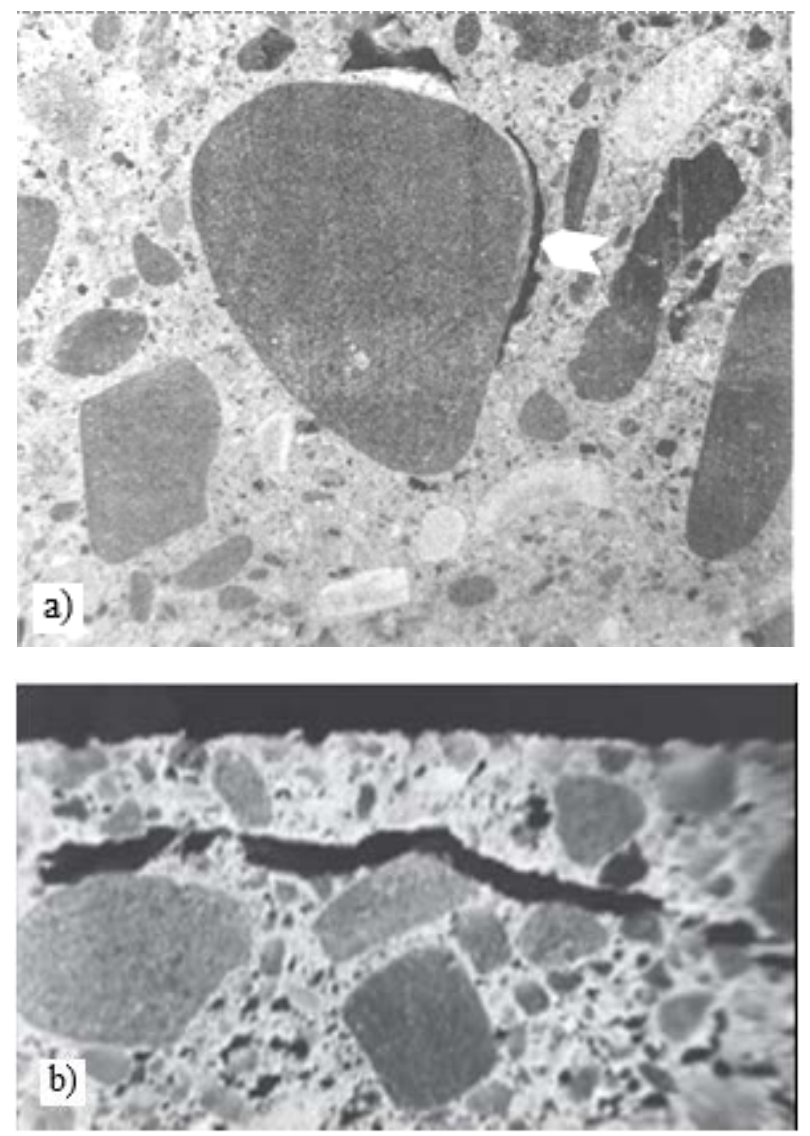

Figure 5. Effect of water migration inside fresh concrete: a) bleeding lens con the surface of an aggregate [33]; b) water blister close to the free-air surface [34].
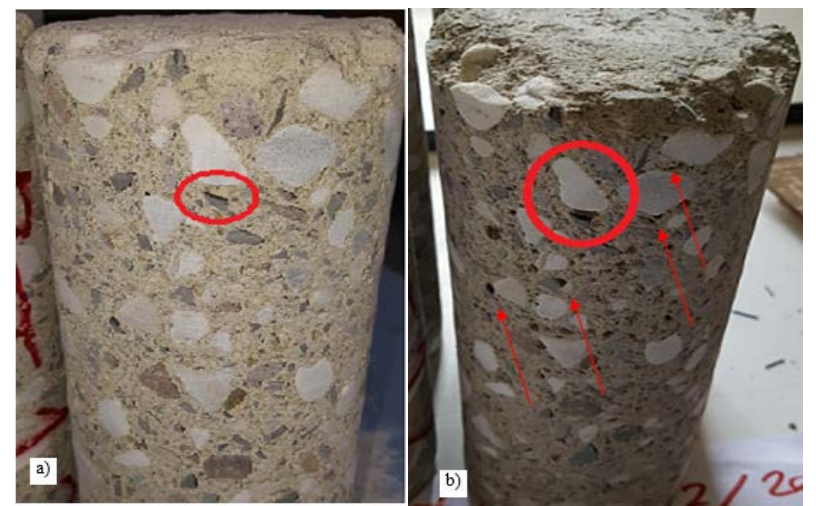

Figure 6. a) MIX $1-\mathrm{w} / \mathrm{c}=1.0$ : high porosity and water lenses on the surface of the aggregates. b) MIX $5-$ w/c $=1.2$ : diffused porosity and water lenses on the surface of the aggregates.

In figures 7 and 8 other data are represented: in [36] the core-to-cubic strength is reported to lie in-between 0.8 and 0.87 , in [39], on the basis of a data set of 640 tests, the average ratio is identified as 0.84 (ranging from 0.60 to 1.00) independent on the concrete strength. The line set at the level 0.70 originates simply from two common code provisions [20, 36 and 37]: cylindrical strength as 0.83 times the cubic one and the core strength 0.85 times the cylindrical one, so that $0.03 \times 0.85=0.705 \cong 0.70$.

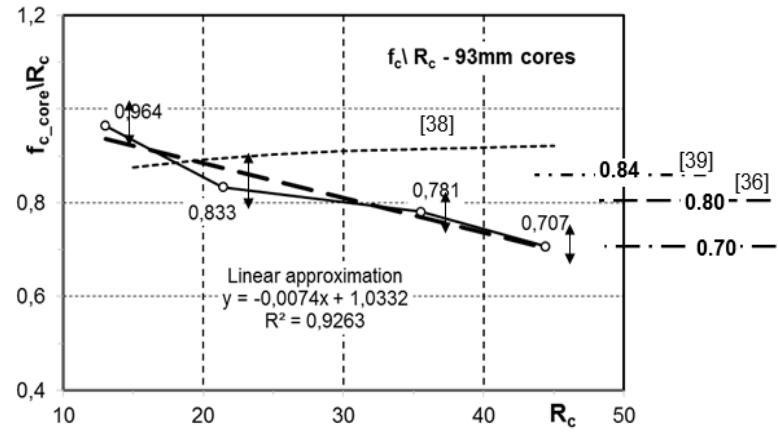

Figure 7. 93mm cores. Core-to-cubic strength vs concrete class

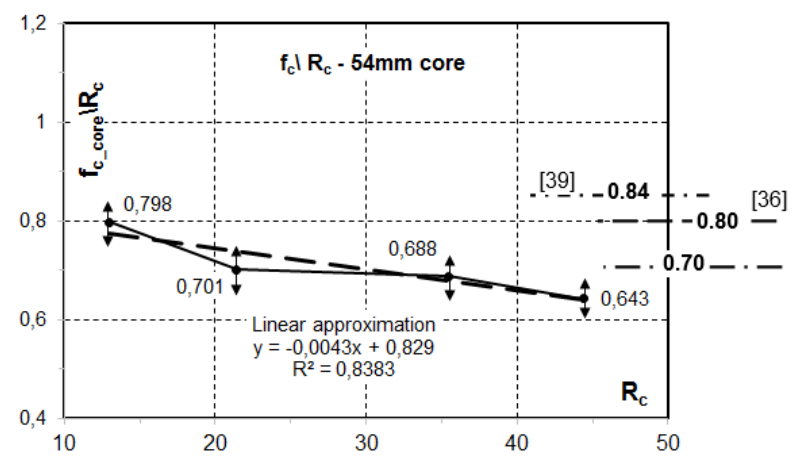

Figure 8. 54mm cores. Core-to-cubic strength vs concrete class
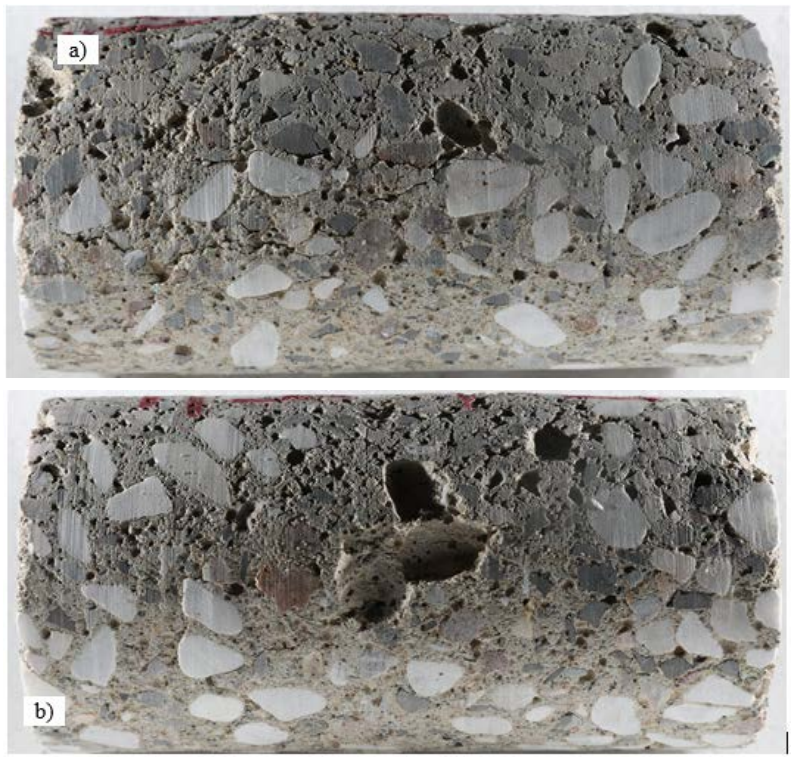

Figure 9. 93mm cores - MIX 5. Large and diffused voids as a result of the water excess. The arrows show the water lenses close to the surface of the aggregates; b) same as a) with detachment of the round aggregates from the core.

Figures 7 and 8 suggest that historical-like concrete is somehow different from modern concrete for substantially two reasons: i) the large water content is responsible for large and diffused voids; ii) the round aggregates are easily detached from the core during drilling. These two features are clearly shown in figure 9.

It has to be noted that the complete detachment of the 
round aggregates from the core is relatively common. Even though the aggregates are not removed from their position, they may be detached from the core thus being responsible of the reduced values of the compressive strength. This assumption is corroborated by the results for the smaller cores, which are systematically lower than the results for the larger cores; the only reason for such an outcome is the detachment of the round aggregates which effects are amplified by the small diameter.

\section{Conclusions}

The usually accepted cubic-to-core strength, usually assumed in-between 0.80 to 0.85 , in some cases may be rather different, ranging from 0.60 to 1.00 [36]. According to some results, [18] and [35] for example, the most common value should be 0.80 approximately. All these data refer to modern concrete, i.e. with adequate aggregate proportioning, proper aggregate quality and proper water/cement ratio. Looking at the test results from the scientific literature $[18,35-41]$ we can see that test data show a dispersion similar to the one showed in figures 7 and 8.

For historical-like concrete, it seems that the effect of cutting damage, during drilling, and of the effect of core diameter, probably connected to the smooth surface of larger aggregates, is much more pronounced than for modern concrete. In this research, the core diameter affects the results $20 \%$ (the $93 \mathrm{~mm}$ core being more resistant than the $54 \mathrm{~mm}$ one) for low strength concrete and some $10 \%$ for high strength concrete. These data would be in-between $5 \%$-to- $8 \%$ for modern concrete.

Considering figure 7 , related to the core diameter of $93 \mathrm{~mm}$ that fits the code standards [20, 21 and 36] (the smaller diameter, $54 \mathrm{~mm}$, would be not coherent with the dimension of the largest aggregate, $25 \mathrm{~mm}$ ) shows that the data provided by codes and literature references are somehow coherent with the outcomes of the research.

A clear effect is the decrease of the core-to-cubic strength ratio for increasing concrete cubic strength. By elimination, we can argue that this effect could be due to the round and smooth surface of the larger aggregates, even though more research is due on this issue. The effect of large aggregates on the behavior of concrete is not new and is still a research issue of the academic community, [40-45] among the others.

The discussion of the test data puts forward a crucial issue in Forensic Engineering: "the strength of the concrete in a specific structure" may be estimated by means of in-situ tests, and drilled cores among these, but the answer will never be "exact" and may have an overall error as large as $\pm 20 \%$, which is not a minor issue for a forensic investigation.

\section{Acknowledgements}

The authors greatly acknowledge the contribution of the technical staff of the Building Materials Laboratory of the University of Genoa, among which Davide Burlando, Giancarlo Cassini, Giuseppe Riotto, Sonia Russo and Giuseppe Tarantino.

\section{REFERENCES}

[1] Malhotra, V.M., Carino, N.J., Handbook on Non Destructive Testing of Concrete, $2^{\text {nd }}$ ed., CRC Press, Boca Raton, 2004.

[2] Bungey J.H., Millard S.G., Grantham M.G., Testing of Concrete in Structures, $4^{\text {th }}$ edition, Taylor and Francis, New York, 2006.

[3] Maierhofer C., Reinhardt H-W, Dobmann G., Non-Destructive Evaluation of Reinforced Concrete Structures, $1^{\text {st }}$ ed., WoodHead Publishing, Sawston, 2010.

[4] Breysse D., Non-Destructive Assessment of Concrete Structures: Reliability and Limits of Single and Combined Techniques, State-of-the-Art Report of the RILEM Technical Committee 207-INR, RILEM, 2012.

[5] Holčapek O., Litoš J., Zatloukal J., "Destructive and Nondestructive Characteristics of Old Concrete”, Advanced Materials Research, Special Concrete and Composites, vol. 1054, pp. 243-247, 2014. doi:https//doi.org/10.4028/www.s cientifi.net/AMR.1054.243.

[6] Ju M., Park K., Oh H., "Estimation of Compressive Strength of High Strength Concrete Using Non-Destructive Technique and Concrete Core Strength”, Applied Sciences, vol. 7, n.12, paper 1249, 2017. doi:10.3390/app7121249

[7] Vasanelli E., Colangiuli D., Calia A., Luprano V.A.M., "Estimating in situ concrete strength combining direct and indirect measures via cross validation procedure", Construction and Building Materials, vol. 151, pp. 916-924, 2017. https://doi.org/10.1016/j.conbuildmat.2017.06.141

[8] Kazemi M., Madandoust R., de Brito J., "Compressive strength assessment of recycled aggregate concrete using Schmidt rebound hammer and core testing”, Construction and Building Materials, vol. 224, pp. 630-638, 2019. https://doi.org/10.1016/j.conbuildmat.2019.07.110

[9] Mather B., Tynes W.O., "Investigation of Compressive Strength of Molded Cylinders and Drilled Cores of Concrete”, ACI Journal Proceedings, vol. 57, n. 1, pp. 767-778, 1961.

[10] Campbell R.H., Tobin R.E., "Core and Cylinder Strengths of Natural and Lightweight Concrete”, ACI Journal Proceedings, vol. 64, n. 4, pp. 190-195, 1967.

[11] Malhotra V.M., “Contract Strength Requirements-Cores Versus In Situ Evaluation”, ACI Journal Proceedings, vol. 74, n. 4, pp. 163-172, 1977. 
[12] Szypula A., Grossman J.S., “Cylinder vs Core Strength”, Concrete International, vol. 12, n. 2, pp. 55-61, 1990.

[13] Bartlett M., MacGregor J.G., "Effect of Moisture Condition on Concrete Core Strengths", ACI Materials Journal, vol. 91, n. 3, paper 91-M21, 1994. DOI: 10.14359/4328

[14] Ariöz Ö., Tuncan M., Ramyar K., Tuncan A., “A comparative study on the interpretation of concrete core strength results”, Magazine of Concrete Research, vol. 58, n. 2, pp. 177-122, 2006.https://doi.org/10.1680/macr.2006.58. 2.117

[15] Tuncan M., Arioz O., Ramyar K., Karasu B., “Assessing concrete strength by means of small diameter cores", Construction and Building Materials, vol. 22, n. 5, pp. 981-988, 2008. https://doi.org/10.1016/j.conbuildmat.2006. 11.020

[16] Bartlett F.M., Kaufman A.L., Richardson D.N., Vogt W.L., "Guide for Obtaining Cores and Interpreting Compressive Strength Results”, ACI 214.4R-10, A.C.I., 2010, 17 pp.

[17] Alwash M., Breysse D., Sbartaï Z.M., “Non-destructive strength evaluation of concrete: Analysis of some key factors using synthetic simulations", Construction and Building Materials, vol. 99, pp. 235-245, 2015.https://doi.org/10.101 6/j.conbuildmat.2015.09.023

[18] Grubbs A.R., Caroll A.C., Schindler A.K., Barnes R.W., "Evaluation of in-place concrete strength by core testing", Res. Rep. n. 2 for ALDOT project 930-828, Highway Res. Center, Auburn, Alabama, 2016

[19] Tur V.V., Derechennik S.S., “Assessment of the Concrete Compressive Strength in Existing Structures Based on Core Test Results", Solid State Phenomemna, vol. 272, pp. 238-243, 2018. https://doi.org/10.4028/www.scientific.net/ SSP. 272.238

[20] ASTM C42-C42M-20, "Standard Test Method for Obtaining and Testing Drilled Cores and Sawed Beams of Concrete”, ASTM, 2020.

[21] ACI 214.4, "Guide for obtaining cores and interpreting compressive strength results”, reapproved 2016, ACI, 2010.

[22] Hellebois A., Launoy A., Pierre C., De Lanève M., Espion B. "100-year-old Hennebique concrete, from composition to performance”, Construction and Building Materials, vol. 44, pp. 149-160, 2013.https://doi.org/10.1016/j.conbuildmat.20 13.03.017.

[23] Sena-Cruz J., Ferreira R.M., Ramos L.F., Fernandes F., Miranda T., Castro F., "Luiz Bandera bridge: assessment of a historical reinforced concrete (rc) bridge”, International Journal of Architectural Heritage, vol. 7, n. 6, pp. 628-652, 2013. https://doi.org/10.1080/15583058.2012.654895.

[24] Brencich A., Nebiacolombo M., “Anchorage of reinforcement bars in Hennebique structures”, Construction and Building Materials, vol. 265, n. 30, paper 120184, 2020. https://doi.org/10.1016/j.conbuildmat.2020.120184.

[25] Marcos I, San-José J.-T., Garmendia L., Santamaria A., Manso J.M., "Central lessons from the historical analysis of 24 reinforced concrete structures in northern Spain”, Journal of Cultural Heritage, vol. 20, pp. 649-659, 2016. DOI: 10.1016/j.culher.2016.03.003

[26] Vosahlik J., Riding K.A., Esmaeily A., Billinger R., McLeod
H., "Effects of air void clustering on concrete compressive strength”, ACI Materials Journal, vol. 113, n. 6, pp. 759-767, 2016. DOI: $10.14259 / 51689241$

[27] Lankard D., Scaglione N., “Discussion to paper [26]”, ACI Materials Journal, vol. 14, n. 5, pp. 819-822, 2016.

[28] Brencich A., Hasweh F., Pera D., "Calibration of Pull-Out Tests on Historical-like Concrete". Accepted for publication in Materials and Structures - RILEM. Publication: January/February 2021.

[29] Fuller W.B., Thompson S.E., "The laws of proportioning concrete”, Transactions ASCE, vol. 59, pp. 67-143, 1907.

[30] ASTM C192/C192M-19 "Standard Practice for Making and Curing Concrete Test Specimens in the Laboratory", ASTM, 2019.

[31] EN 12390-2, “Testing hardened concrete. Part 2: Making and curing specimens for strength tests”, C.E.N., 2019

[32] Hoshino, M., "Relationship between Bleeding, Coarse Aggregate, and Specimen Height of Concrete," ACI Materials Journal, vol. 86, n. 2, pp. 195-190, 1989.

[33] Kosmatka S., "Bleeding”, in Significance of Tests and Properties of Concrete and Concrete-Making Materials, West Conshohocken, PA, ASTM International, 1994, pp. 88-111.

[34] Concrete in Practice 13 - Blisters on Concrete Slabs, NRMCA, CIP series, https://www.heritageconcrete.net/reso urces/concrete-fact-sheets/concrete-in-practice-13-concreteblisters/ (accessed Jan. 14, 2021).

[35] Bartlett M., MacGregor J.G., "Equivalent Specified Concrete Strength from Core Test Data”, Concrete International, vol. 17, n. 3, pp. 52-58, 1995.

[36] BS EN 13791: 2019, “Assessment of in-situ compressive strength in structures and precast concrete components", B.S.I., 2019.

[37] EN 13791: 2019: "Assessment of in-situ compressive strength in structures and precast concrete components", C.E.N., 2019.

[38] Indelicato F., "Estimate of concrete cube strength by means of different diameter cores: a statistical approach”, Materials and structures, vol. 30, pp. 131-138, 1997.https://doi.org/10 .1007/BF02486384

[39] Tran N.L., Graubner C.A., "Uncertainties of concrete parameters in shear capacity calculation or RC members without shear reinforcement”, Beton-und Stahlbetonbau, vol. 113, issue S2, in International Probabilistic Workshop, Wien, February 2018. https://doi.org/10.1002/best.201800059.

[40] Issa S., Islam M., Issa M., Yousif A., "Specimen and Aggregate Size Effect on Concrete Compressive Strength." Cement, Concrete and Aggregates, vol. 22, n. 2, pp. 103-115, 2000. https://doi.org/10.1520/CCA10470J

[41] Meddah M.S., Zitouni S., Belâabes A., "Effect of content and particle size distribution of coarse aggregate on the compressive strength of concrete", Construction and Building Materials, vol. 24, n. 4, pp. 505-512, 2010. https://doi.org/10.1016/j.conbuildmat.2009.10.009.

[42] Yi C., Ban S.L., Cui J.Y., Chen G., Song Y.P., "Effect of 
Specimen Shape and Size on Compressive Strength of Concrete”, Advanced Materials Research, vol.s 163-167, pp. 1375-1379, 2010. https://doi.org/10.4028/www.scientific.ne t/amr.163-167.1375

[43] Sim J.-I., Yang K.-H., Jeon J.-K., “Influence of aggregate size on the compressive size effect according to different concrete types”, Construction and Building Materials, vol. 44, pp. 716-725, 2013.https://doi.org/10.1016/j.conbuildma t.2013.03.066
[44] Yehia S., Abdelfatah A., Mansour D., "Effect of Aggregate Type and Specimen Configuration on Concrete Compressive Strength”, Crystals, vol. 10, n.7, paper 625, 2020. https://doi.org/10.3390/cryst10070625

[45] Osuskà L., Hela R., “The Impact of Different Aggregate Types and its Composition on Resulting Concrete Properties representing the Water Impermeability Level of Concrete for the Construction of White Boxes, Civil Engineering and Architecture, vol. 8, n. 2, pp. 39-45, 2020. DOI: 10.13189/cea.2020.080201 